\title{
Chapter 3 \\ Global Burden of Violence and Other Human Rights Violations Against Sex Workers
}

\author{
Elena Argento, Kay Thi Win, Bronwyn McBride, and Kate Shannon
}

\section{Introduction}

Every person possesses the right to freedom from torture, inhumane treatment, and the right to recognition before the law. These rights are not invalidated if a person sells sex or is suspected of a crime. However, globally, sex workers continue to experience disproportionate rates of violence and other human rights violations. A systematic review in 2014 identified a staggeringly high lifetime prevalence of physical, sexual, or combined workplace violence against women sex workersfrom $45 \%$ to $75 \%$ [1]. Although these violations of sex workers' rights remain largely overlooked within international agendas on violence prevention, over the last decade, sex workers and advocates have upheld the human rights framework to document them [2-4]. As a result, increasingly, the unacceptable violence faced by sex workers is being addressed in international guidelines [5-7].

The intersection of macro-structural factors (e.g. laws/policies, stigma, poverty, racism, transphobia/homophobia, cultural norms) and community-level factors (e.g. policing, working conditions, access to health, and peer-led services) influences the risks of experiencing violence among sex workers and their access to recourse on a global level [8-11]. A recent systematic review identified major structural factorsthe criminalisation of sex work and resulting punitive policing, work environments, and gender and economic inequities - as shaping the vulnerability of sex workers [1]. Criminalisation is a key determinant of sex workers' access to safer indoor work

\footnotetext{
E. Argento $\cdot$ B. McBride $\cdot$ K. Shannon $(\bowtie)$

Centre for Gender \& Sexual Health Equity, Vancouver, BC, Canada

University of British Columbia, Vancouver, BC, Canada

e-mail: elena.argento@bccsu.ubc.ca; bronwyn.mcbride@cgshe.ubc.ca;

Dr.Shannon@cgshe.ubc.ca

K. T. Win

Asia-Pacific Network of Sex Workers (APNSW), Bangkok, Thailand

e-mail: kaythi@apnsw.info
} 
environments, supportive third parties, and labour and police protections [1]. Criminalisation also contributes to the devaluing of sex workers' social status, which increases their vulnerability to violent perpetrators. Sex workers often hesitate to report incidents to police, due to deep-rooted mistrust and fear of criminal charges, stigma, or further abuse [12-16]. This inability to access justice enables perpetrators to abuse sex workers with impunity, perpetuating high levels of violence [16-20].

Guided by a structural determinants framework [8], this chapter provides an overview of the socio-structural factors shaping violence against sex workers. We summarise findings from academic research, and feature examples of sex workers' lived experiences as well as case studies from Asia-Pacific Network of Sex Workers (APNSW), a sex worker initiated and led organisation representing sex worker organisations in Asia and the Pacific. In recognising the right to live and work free from violence as a human right, we aim to provide an evidence base to inform the development of policy and public health interventions to promote safety for sex workers worldwide.

\section{Interpersonal Violence from Clients and Intimate/Non-paying Partners}

Globally, sex workers of all genders experience elevated rates of violence. Among women sex workers working mostly in street-based settings, an estimated 32-55\% experienced workplace violence by any perpetrator in the last year [9].

Violence experienced by sex workers varies substantially in nature and degree, depending on their working environment (e.g. managerial and policy features of venues) and community-level factors (e.g. empowerment) [9]. In many settings, sex workers experience physical and sexual violence perpetrated by clients and by predators posing as clients, often during negotiation around the use of condoms. This is a violation of sex workers' labour rights and increases their risk of exposure to HIV and sexually transmitted infections (STIs) [21-28]. Sex workers also suffer violence from intimate partners, including threats of exposure to police as a form of domination and control $[29,30]$. Global estimates of combined physical and sexual violence by intimate partners over lifetime range from $4 \%$ to $73 \%$ [9], and the homicide rate among sex workers in the USA is approximately 17 times the rate of the general population [29]. In Canada's worst serial murder case, 67 women-most of whom were sex workers, and many of whom were Indigenous-were murdered or went missing from Vancouver between 1997 and 2002. This case received widespread scrutiny regarding inaction on the part of police and the judicial system, reflecting pervasive stigma and the devaluing of marginalised women involved in sex work [12].

The following community case study conducted by APNSW describes how violence from various perpetrators has become normalised a sex workers. This is how 
one sex worker described an experience of severe physical/sexual client violence in Bangladesh:

I am 30 years old. I am a sex worker over the last 8 years in Dhaka. Violence is part of our daily lives. We face violence from police, clients, boyfriends, family and the public. There is not a single day we don't face violence. However, two months ago I faced serious violence from some clients. A group of 4 people took me in a night in an under-construction building. They all were on drugs and also took sex drugs. The first person did sex with me a minimum of one hour and I was feeling pain and after the second person, I told them I cannot do sex anymore. They were very angry and they forced me to do sex. After the third client I had severe pain. I was crying and told them to allow me to go. They become very angry and bit me seriously. At one point they pushed a beer bottle in my vagina. I felt serious pain. After that I was crying, and then security people came and sent me to home. I was feeling pain for two days in my abdomen. I could not tell anyone that inside my body was a bottle. Then I called my sex worker friend. She took me to a clinic. The doctor said situation is so serious and I needed an operation. It was expensive but my friend helped me to do the operation. I am so grateful to my friend.

Qualitative research among street-based sex workers has documented pervasive gender inequality and their experiences of psychological dominance by males within intimate partnerships. This work underscores the impact of gendered power imbalances directly influencing women's agency and their ability to safeguard themselves against risky sexual behaviours. Such behaviour also normalises violence within the context of multiple forms of oppression such as poverty, racism, and economic dependence on partners [31-35]. Qualitative research from India among men, trans, and women sex workers has described the ways in which collectivisation and community empowerment can reduce violence from clients and police, but also indicates an increase in violence from sex workers' male intimate partners, attributed to those partners feeling threatened by shifts in the balance of power in their relationships [36].

\section{The Impacts of Criminalisation}

Punitive, enforcement-based approaches continue to undermine the health of sex workers [5, 8, 37]. A Lancet review determined that rights violations against sex workers are most profound where aspects of sex work are criminalised [29]. Under criminalisation, violence occurring in the context of sex work (i.e. as a workplace hazard/harm) is not monitored by any formal bodies; due to this omission, few to no legal protections are afforded to sex workers [38]. Violence against sex workers often goes unreported and is seldom registered as an offence. In some cases, it is perpetrated by police, exacerbating trauma and further restricting sex workers from accessing justice, health, or social services [9, 26, 39].

Violence against sex workers is largely shaped by criminalisation and contemporaneous stigma, discrimination, and social marginalisation [8, 29, 40]. These structural factors impact health access and outcomes, leading to heightened physical risks (e.g. violence, injury, death, HIV/STIs) [9, 38, 41] and mental health harms 
(e.g. addiction, depression, anxiety, post-traumatic stress disorder) [42-44]. Criminalisation also hinders collectivisation among sex workers, a factor critical to building capacity among sex workers and which enables them to negotiate safety in the workplace, advocate for labour protections and demand equal access to health and social services [36, 37, 45-47].

International bodies including the World Health Organization, UNAIDS, and Amnesty International have endorsed the full decriminalisation of sex work as necessary to promoting sex workers' human rights $[5,7,48]$. Despite this, the dominant socio-legal response to sex work remains criminalisation through punitive law. Criminalisation models can prohibit all aspects of sex work, or certain aspects, such as soliciting, advertising, collective working, or third party involvement [49]. Legalisation models-implemented in parts of Australia, Switzerland, Turkey, Hungary, Germany, the Netherlands, Nevada (USA), and Mexico—-typically feature regulatory conditions (e.g. mandatory licencing or registration, mandatory HIV/STI testing) that are often discriminatory and enforced through criminal law [29, 49]. In 1999, Sweden criminalised the purchasing of sexual services (but not the selling of sex). This approach focuses on targeting clients and third parties and has generated a global wave of such "end-demand" legislation. Initial evidence on the impacts of end-demand laws suggest that even policies purportedly designed to criminalise only clients and third parties continue to indirectly criminalise sex workers and undermine sex workers' labour conditions, health, and human rights.

Research evaluating the impact of Canada's new end-demand laws (Protection of Communities and Exploited Persons Act; PCEPA) in Vancouver found that sex workers had significantly reduced access to health and community-led services as a result of the implementation of end-demand criminalisation [50]. Qualitative findings from Sweden and Canada underscore that criminalising clients reproduces the harms of full criminalisation models [51, 52]. Similarly, research from France found that end-demand laws undermined sex workers' safety and overall living conditions-exacerbating, rather than reducing, the harms associated with the previous laws against soliciting [53]. Conversely, evidence from New Zealand, which decriminalised sex work in 2003 (but only for New Zealand citizens), and New South Wales, Australia, has highlighted improved workplace safety, working conditions, and access to police protections for sex workers under full decriminalisation [54-56].

In Bangladesh, where sex work is legalised and regulated, sex workers face a lack of recourse after experiencing violence. The following APNSW case study illustrates how a sex worker and "ghorwali" (third party who provides space to sex workers and takes commissions) did not feel she could report violence and extortion to police.

It was a Friday evening at 8:00 pm; 4 young people entered my house. They said that I'm a bad woman and I take clients. At that time, in my house were two girls (sex workers) and 3 clients. They asked me who are those girls and boys... and started to be slapping the boys. The clients were scared and started to cry. The girls were scared too. They took money by force from clients... They were shouting and slapping me...telling me if I give them 20,000 BDT [Bangladeshi taka] and allow them to have sex with the girls then they will leave my 
house. All 4 young boys did sex with girls by force and we were scared so we could not protect them. However, after sex they again asked for 20,000 BDT. In this point, I started to cry and... the house owner heard. At this point, they left without money from me.

One night a week later, my client came to my house. All 4 bad boys again entered my house. The boys start to slap [my client] and asked 10,000 BDT. They threatened to take naked pictures and post on Facebook. The client was scared and gave them 5000 BDT. After that, they saw my 15-year-old daughter... they demanded to have sex with my daughter. My daughter was scared and started to cry. I called Morzina (HARC [HIV/AIDS Research and Welfare Centre] paralegal) and told her to come with police. At this point the bad boys... said we will go if I gave them 5000 BDT. As they were asking for my daughter, I was scared. I gave them 5000 and they left.

After that, I went to HARC office for next steps. They gave me two suggestions, one to do a general diary to the police station mentioning their names, or to change house as now everybody knew that I was involved in sex work. I took the second option and moved to a new house. I am continuing work but not sure what will happen next. I told the house owner that I work at HARC office...but I'm not sure how long I can stay in this house.

\section{Police Repression, Extortion, and Abuse}

Criminalisation enables police abuses against sex workers, for example, harassment and threats; fines, bribes, or other financial extortion; confiscation of condoms; assault; extorting sex under threat of arrest, all of which have been documented in diverse contexts [14, 16, 57-63]. Such punitive policing practices have been reported by sex workers globally as proxies for enforcement of sex work laws, dynamically influencing experiences of violence and the ability of sex workers to negotiate safer sexual transactions with clients [22, 24, 64-71]. Trans sex workers are especially vulnerable to being targeted by police and are subjected to discrimination and greater levels of violence $[25,72,73]$.

Among sex workers in Canada, violence by police and enforced displacement to isolated outdoor locations are independently associated with their experiences of violence from clients [65]. Studies evaluating policing guidelines that prioritised targeting clients and third parties over arrest of sex workers in Vancouver, Canada, found increased likelihood of rushed negotiations with clients due to police presence [74], and no reductions in violence [70, 74].

Globally, police are primary perpetrators of violence against sex workers, further undermining their access to criminal justice systems. Gang rape and forced unprotected sex by police officers while being arrested and detained have been documented among sex workers of all genders [21, 28, 30, 39, 75-78]. Estimates of police-perpetrated sexual violence vary widely from $7 \%$ to $89 \%[9,21,29,67,75$, 78]. Police further violate sex workers' rights by extorting money or sex, frequently under threat of arrest $[39,75,79]$. Police harassment has also been independently associated with increased odds of workplace violence among sex workers in Canada, Ivory Coast, and India [65, 67, 80], and a meta-analysis demonstrated that sex workers who have been exposed to repressive policing were significantly more likely to experience violence from clients and others [49]. 
The following APNSW case study excerpts describe sex workers' lived experiences with extortion, severe violence, and detainment by police across diverse countries. These narratives underscore the urgency of addressing punitive policing practices to improve the safety of sex workers.

Over the last 7 years, I faced many different types of violence, but the terrible experiences were with police. I was arrested 2 times. The first time was 5 years ago. Police asked me to give money but I had no money. After that I was in police station for a night and then transferred to court. I had no one to help me, I couldn't even understand what type of allegation was against me but had to go to jail for 15 days. I had a 1-year-old daughter and she faced serious problems. One of my relative took care of her, but she was poor too, so, my daughter could not get proper food for many days. After 15 days when I came back from jail, I was afraid to work too, so I spent many days without food. Second time I was arrested 2 years ago, with a client. Police only arrested me and did not say anything to the client. However, when police put me in the car going to the police station, I jumped from the moving car and ran away. We have many experiences but there is no one to listen to our issues. We are also human, we have also rights to live like other women, but we cannot because we are sex workers.-sex worker, India

In my sex worker life, I've experienced many different types of violence. Now, the biggest problem is police violence. Police usually arrest us on Friday night, then keep us in the police station where there is no food, no water, no toilet, no shower facilities. We often need to do sex with police there too. They keep us for two days just to get money and sex. Finally, police transfer to court on Sunday. I was arrested on Friday and was in the station for two nights. I did sex with two policemen. However, just before transfer to court on Sunday morning, my pimp released me from the police station. He told me he spent 10,000 (125 USD) and I have to pay 15,000 (200 USD) in a year. I could not pay because my income was not that high. Finally, I gave back 22,000 (300 USD) in two years. I had to do so much work just to give back money, and often I could not eat properly.-sex worker, Bangladesh

I was arrested by police 3 times. First time when I was only 20 years old and just 6 months after starting sex work. Police arrested me and kept me in the station for 3 days. I had sex with 6/7 police in those 3 days and was in jail for one year. I had to do sex in jail with jail police too. After coming back, I started sex work and within a year I got arrested again by police, same situation, 3 days in the police station and sex with many police. That time I was in jail for 3 months. After coming back, I stopped sex work. I thought, I cannot go to jail again as it's painful. So I got married and thought to continue housewife life. After 2 years I got divorced, I had a son, so again I was in a bad situation. I started sex work again. Finally, I got arrested in February 2018. After arrest, I called my relatives to loan money to get out. One gave money to police so I got released. Now I feel to stop sex work, but on the other hand, I need food, and there is no alternative work for me because I am not educated.-sex worker, Myanmar

\section{Impact of Violence on HIV/STIS}

The failure of the state to protect sex workers from violence and other human rights abuses has shaped epidemic rates of violence and HIV/STIs against sex workers globally [9, 49]. Violence by any offender reduces the ability of sex workers to safely negotiate transactions (e.g. types of sex acts, condom use), constrains their 
choices and heightens vulnerability [38]. Violence-physical and sexual-is the most influential determinant of HIV/STI risk among sex workers, associated with inconsistent condom use and refusal by clients to use condoms [45, 81-83].

Violence from the state, clients, individuals posing as clients, or intimate partners - together with unlawful arrest, detention, and discrimination-have severe effects on the HIV/STI-related inequities faced by sex workers. Punitive approaches to sex work hinder HIV prevention [84, 85], criminalisation, incarceration, and legal restrictions on sex work constrain sex workers' agency and access to safe working conditions. They also elevate HIV/STI exposure through increased violence [29, 76, 83]. In Argentina, India, and China, arrest, extortion, condom confiscation, and physical/sexual violence by police have been shown to significantly reduce condom use with clients and intimate partners [64, 66, 68, 86]. A global meta-analysis demonstrated that sex workers who experienced police violence faced a significantly higher HIV and STI burden [49]. In contrast, modelling estimates indicate that decriminalisation of sex work (i.e. removal of all laws targeting the sex industry) could avert up to $46 \%$ of new HIV infections among sex workers and their clients over a period of 10 years [8].

In criminalised contexts, the structural violence of stigma and discrimination (e.g. from police and healthcare providers) prevent sex workers from carrying condoms and hinder efforts to increase sex workers' access to health services [21, 77, $87,88]$. Police surveillance limits sex workers' ability to negotiate client condom use by forcing sex workers to rush transactions and client screening and displaces sex workers to isolated locations, increasing their vulnerability [34, 52, 89].

Alarmingly, across global contexts, police use possession of condoms as evidence of sex work to justify arrest, making it difficult for sex workers to safely access needed HIV/STI prevention supplies [38, 56, 76]. Condoms have also been used as evidence to target third parties and sex work businesses, which can undermine sex workers' access to condoms in the workplace [90].

Community perspectives from ANSWP echo these concerns. For example, the following case study describes a sex worker's experience of police using possession of condoms to justify arrest and abuse in Papua New Guinea:

A female sex worker was thoroughly checked by police [...] when she was dressed to go to a nightclub to do her sex work. A police car drove by and all of a sudden, stopped and reversed to where she was. Two policemen came out with a gun and pointed it at her and asked where she was going. One got hold of her small ladies'bag and opened it up, and saw condoms and her makeup. They asked her to get into the car and drove her to the police station, locked her up and raped her, and one took photos and videos. She was also asked to use her condoms to blow and make balloons and play with them. We finally found out the next day after one sex worker called me, the vocal person. When we tried to file the matter and take the police to court, the lawyer who was engaged to hear the case never showed up. We are still trying to carry out the case, but the sex worker told me she's scared of the policemen in case they will murder her if she's found alone. My advice to her is that; if we take them to court, they will not do that to us and if we ignore, we will face this for the rest of our lives. 


\section{Forced Rehabilitation and Mandatory Testing}

Forced or mandatory 'rehabilitation' and detention of sex workers often occur under the guise of anti-trafficking efforts which conflate sex work (consensual exchange of sexual services) with forced sexual labour. Sex workers have faced rape and other physical violence during forced rehabilitation (i.e. programmes designed to force sex workers to exit/leave sex work) [91], and police have been documented as using forced HIV testing as a means of exploitation and harassment, including during detention and following police raids [75, 92]. In China, Cambodia, and India, sex workers have faced forced confinement, forced labour, forced HIV/STI testing, and poor treatment, including unhygienic conditions and denial of medical services [91, 93, 94]. In China, sex workers and clients have been detained for up to 2 years without trial in the so-called education and rescue centres and subjected to forced labour [93], sharply highlighting the hypocrisy of attempts to "rescue" sex workers from what the state deems to be exploitative labour. Mandatory HIV testing of sex workers is considered a rights violation by the UN Refugee Agency and UNAIDS, as it creates barriers to accessing services by facilitating discrimination against sex workers living with HIV [49]. In Nevada, USA, sex workers who test positive for HIV can face up to 10 years in prison [95].

\section{Strategies for Change: A Human Rights Framework and Community-Led Interventions}

To achieve human rights objectives and address violations such as unacceptable levels of violence against sex workers, a human rights framework and an approach using structural determinants are required [29, 83]. This means targeting punitive laws, policies, and resulting repressive policing. It also requires the promotion of enabling environments fostering community empowerment and partnerships, whereby sex workers can take collective ownership of programmes to address social and structural barriers to health, safety, and human rights [47].

Robust evidence has demonstrated that sex work criminalisation forces sex workers into adversarial relationships with police, increasing their vulnerability and restricting their access to legal protections $[8,37,64,96]$. As such, the full decriminalisation of sex work, reform of policing practices, and facilitation of access to safer work environments are urgently needed. In South India, successful community-led approaches to reducing violence and HIV, improving access to justice, and challenging institutional stigma offer examples of what can be achieved with sustained funding and support [36, 46, 77, 78, 97].

Building on evaluations of community-led HIV prevention interventions conducted in lower-middle income countries (namely India, Dominican Republic, and Brazil [47]), community-based and biomedical HIV interventions should be integrated to ensure human rights outcomes and consider rights-related barriers to success. Sex workers of all genders should have meaningful roles in these efforts. 


\section{Case Study: Response to Violence in Asia Pacific}

The End Violence against Sex Workers (EVASW) project in Myanmar is a sex worker-led, community-based initiative which has proven successful and costeffective in addressing factors that contribute to sex workers' vulnerability to abuse (see Box 3.1). However, broader structural changes, such as legal reform, are necessary to facilitate the work of community-led organisations.

\section{Box 3.1 Ending Violence Against Sex Workers in Myanmar}

Violence against female and trans sex workers is pervasive in Myanmar, and police are both primary perpetrators of violence and key gatekeepers to sex workers' rights. This project aims to improve the safety of and promote access to justice for sex workers in four cities across Myanmar, and also aims to reduce discrimination and stigma against them, by February 2020. It aims to increase sex workers' knowledge of their rights, empower collective action to prevent and respond to violence, and advocate for structural change to reduce sex workers' vulnerability. Key factors to successful reduction of violence include greater collective agency among sex workers, enhanced self-efficacy contributing to greater use of crisis response mechanisms, and relationshipbuilding with stakeholders. In a South-South partnership between APNSW members Ashodaya and Aye Myanmar Association (AMA), this approach has been adapted to Myanmar's context and implemented with support from APNSW. Because sex work is criminalised in Myanmar, special measures for ethics and safety have been taken.

Sex workers have learned about human rights through legal literacy and court process workshops hosted by AMA. A violence response team, made up of a core cadre of sex worker leaders, has been created. AMA encourages sex workers to report violence through the response team and by using technology called iMonitort: a mobile app that sex workers can use to document violence with photos and videos. When sex workers report information using iMonitor+, the violence response team responds with action. AMA also continues to work to establish institutional partnerships between the community and police to address stigma and discrimination. Through sensitisation workshops and advocacy meetings, law enforcement officers gain an enhanced appreciation of violence against sex workers, and of their own roles and capacity in response. These strategies are in the process of being systematically implemented within interventions to reduce violence against sex workers in Myanmar. Successes include meetings with police and the uptake of reporting and documenting violence against sex workers. AMA has received reports of some officers assisting sex workers after learning more about sex workers' lives. 
APNSW and its members have developed a rapid-response programme which was pioneered in Myanmar and is now being adapted and implemented in four countries in Asia (see Box 3.2). The following excerpts describe how the programme in Myanmar (AMA) has provided legal assistance and protection for sex workers who have been incarcerated.

I learned about the AMA program 4 months ago when I met with outreach workers downtown. I learned that AMA helps sex workers from violence and if police arrest them, they help them to get released without any money. After this I was thinking about my past. When I was 30 years old, police arrested me. I was in jail for one year. I had a 3-year-old boy when I went to jail. After release, I could not find my son. Until today, I don't know where my son is! At that time, there was no program, no communication system with anyone from jail. Now, the situation is totally changed. I was arrested again in February, and I called my outreach workers. The police sent me to court; the AMA legal officer was there and she talked for me in court. I got released but my case is still active. I need to go to court twice a month but I am free and can work like any other sex worker. Now I think, if this project was here 20 years ago, I would not have lost my son. This project is a great help for sex workers.—sex worker, Myanmar

I've done sex work for the last 8 years. In the past, I was arrested by police and got released by spending over 500,000 MMK (500 USD). However, I was arrested in 2017 and the court sent me to jail. My case was not finished so I had to come to court twice a month from jail. I got an AMA hotline card in jail from another sex worker. I sent the hotline number to my daughter, who called and requested help. In January when I came to court, the AMA legal officer talked in court about my case. I got released. Now I am free and living with my family. My case is still active, but I have no problem because I can work like others. I am so happy with AMA; if AMA didn't help me, I could be in jail for a long time. AMA is saving the lives of sex workers in Myanmar--sex worker, Myanmar

\section{Box 3.2 Ending Violence Against Sex Workers in Bangladesh, Indonesia, Myanmar, and Nepal}

Safety First is a programme to reduce violence against sex workers, comprised of human rights documentation, legal rights training, legal services, and a crisis hotline. APNSW implements the Safety First project with four established partner organisations: HIV AIDS Research and Welfare Centre (HARC, Bangladesh), Organisasi Perubahan Sosial Indonesia (OPSI, Indonesia), Aye Myanmar Association (AMA, Myanmar), and Jagriti Mahila Mahasang Sanghta (JMMS, Nepal). Over the last 2 years, APNSW has provided intensive technical support to all four organisations.

Safety First uses rights-based interventions designed by female sex workers, based on their recommendations for the most effective local interventions. It involves four peer-led service components, including a safe space, outreach, a hotline, and legal services.

Safety First starts with know-your-rights trainings and legal education held in the safe space. Sex workers trained to be paralegals offer legal counselling in the safe space every working day. Legal counsellors also document human rights violations and proceed with representation in court or pursuing legal 
Box 3.2 (continued)

action on behalf of sex workers. The sex worker community experts developed a violence reporting form during the regional training. Each quarter, a lawyer will come to the partner organisation's office to meet sex workers and explain court procedures, the rights of a person who has been arrested, and how sex workers should respond to police harassment/arrest. A lawyer is always standing by in court to assist sex workers with pro-bono representation and legal advice.

Outreach is conducted in sex work venues by peer educators to promote Safety First's services. Each partner organisation has recruited three peer outreach workers for a Rapid Action Team (RAT), who all carry mobile phones. Sex workers call the hotline or outreach workers when they experience or witness violence. The RAT responds to hotline calls, goes to police stations and court when sex workers are arrested, and documents violence using the form developed during the regional meeting.

The RAT also conducts advocacy and sensitisation meetings with police, building on earlier police advocacy work. These sessions aim to reduce the number of sex workers being arrested, by sensitising police to the marginalisation, stigmatisation, and harassment facing sex workers. Additional advocacy meetings take place with high-level commanding officers to create opportunity for meaningful exchanges between law enforcement and sex workers.

Safety First team members accompany sex workers who have experienced violence when they seek health care, and OPSI, the Indonesian Safety First partner, has successfully advocated in medical settings for confidentiality around being a sex worker and HIV status.

Safety First has demonstrated success in reducing violence against sex workers. In Myanmar, the RAT receives an average of 20 calls each month, in addition to calls to the hotline. Sex workers who received legal advice and representation from Safety First experienced better outcomes in court. The success of Safety First programming demonstrates that community-based programmes can effectively reduce violence and its impacts on HIV transmission within an enabling environment. This programme also demonstrates the need to involve higher level stakeholders including governments, NGOs, and law enforcement to increase safety for sex workers.

\section{Box 3.3 Lessons Learned from APNSW}

APNSW works to end violence by empowering sex workers and encouraging collective action, and this approach has demonstrated to generate positive results. For example, sex workers now inform one another about police movements by mobile phone, and when police arrest any sex worker, others call the hotline to inform paralegals to take necessary action. When police arrest sex 
Box 3.3 (continued)

workers, other sex workers go to the police and try to help them to get released. In the past, sex workers would never dare question or confront the police.

As violence is a multi-dimensional issue, multiple partnerships are critical. In all four countries, APNSW built meaningful partnerships with government, police, and the National AIDS Programme (NAP) under the Ministry of Health. NAP clinics in project areas agreed to provide health services to sex workers after they have experienced assault. Within the Government sector, during township-level inter-governmental meetings, NAP staff strongly highlighted the issue of violence against sex workers. These statements also helped when it came to advocacy work with police. Global experience shows that partnership with Ministries of Health and other stakeholders are essential to bring about sustainable institutional change to address violence against sex workers.

Access to legal services have direct impacts on community empowerment, confidence-building, and overall reduction of violence. Outreach workers of APNSW partners found that sex workers at the community level are now aware of legal aid services. In Myanmar, community members follow the progress of legal cases in the courts through informal sex worker networks. These cases build confidence among sex workers, who realise that they are not alone-there are people to help them-and this realisation itself is empowering. Now, after being arrested, $65 \%$ sex workers are released, either before being taken to the police station or from the station.

There has been excellent uptake of our hotline and direct calls to outreach workers, where sex workers report experiences of violence. APNSW is also working with media to promote positive, non-stigmatising reporting about sex workers, and is documenting rights violations against sex workers. Over 745 cases in each country have been documented, and we qualitatively analysed each case for use in advocacy with journalists and in Government meetings. This process of documenting human rights violations helps to amplify community voices.

A 2015 UN and APNSW sex worker-led, multi-country study in Asia Pacific produced recommendations on the reduction of violence against sex workers [98]. It underscored the need to end impunity among violent predators; strengthen sex workers' access to justice, and improve sex workers' access to non-discriminatory health, HIV/STI, and violence crisis services.

\section{Recommendations for Programming and Policies [98]:}

1. Reform punitive laws and law enforcement practices to uphold sex workers' right to be free of violence

2. End impunity for those who commit violence against sex workers by holding perpetrators accountable for crimes 
3. Strengthen sex workers' access to justice and support sex worker-led legal advocacy

4. Recognise sex work as legitimate work and ensure that sex workers have legally enforceable rights to occupational health and safety protections

5. Improve sex workers' access to sexual and reproductive health, HIV and gender-based violence services

6. Full decriminalisation of sex work to ensure labour rights for sex workers

7. Uphold anti-discrimination and other rights-respecting laws

8. Ensure available, accessible, and acceptable health services for sex workers

9. Address violence against sex workers in all health and HIV programmes

10. Support community empowerment and sex worker-led programming and remove laws restricting sex workers' ability to formally organise

\section{Conclusions and Future Directions}

Academic literature and lived experiences of sex workers and sex worker-led organisations overwhelmingly indicate that there remains an urgent need to improve the safety and human rights of sex workers worldwide. Criminalisation, stigma, and discrimination interact to reproduce sex workers' exposure to violence, and hinder efforts to enact change. Community empowerment approaches that facilitate sex worker organising are effective strategies to promote sex workers' rights. Interdisciplinary, mixed-method and participatory research is needed to further document the impacts of criminalisation and violence on sex workers' health and their access to health and legal services, as well as to inform context-specific interventions. Legislative reforms to decriminalise all aspects of sex work; political commitment to reduce structural inequalities, stigma, and exclusion; and funding to scale up sex worker-led services are evidence-based, rights-based strategies proven to mitigate risk of violence, to ensure safer work environments, and to uphold human rights among sex workers globally.

\section{References}

1. Deering KN, Amin A, Shoveller J, Nesbitt A, Garcia-Moreno C, Duff P, et al. A systematic review of the correlates of violence against sex workers. Am J Public Health. 2014;104(5):42-54.

2. Ditmore MH, Allman D. An analysis of the implementation of PEPFAR's anti-prostitution pledge and its implications for successful HIV prevention among organizations working with sex workers. J Int AIDS Soc. 2013;16:17354.

3. FIDA. Documenting human rights violation of sex workers in Kenya. Nairobi: FIDA; 2008.

4. International Committee on the Rights of Sex Workers in Europe. Sex workers in Europe manifesto. Brussels: International Committee on the Rights of Sex Workers in Europe; 2005.

5. World Health Organization. Prevention and treatment of HIV and other sexually transmitted infections for sex workers in low- and middle-income countries - recommendations for a public health approach [Internet]. Geneva; 2012 [cited 2017 Sep 6]. Available from: http://www. who.int/hiv/topics/sex_worker/en/. 
6. UNAIDS. UNAIDS guidance note on HIV and sex work. WHO Libr Cat Data [Internet]. 2009 [cited 2018 Jan 17];(2009):23. Available from: http://www.unaids.org/sites/default/files/ media_asset/JC2306_UNAIDS-guidance-note-HIV-sex-work_en_0.pdf.

7. Global Commission on HIV and the Law. Risks, rights \& health. New York: Global Commission on HIV and the Law; 2012.

8. Shannon K, Strathdee SA, Goldenberg SM, Duff P, Mwangi P, Rusakova M, et al. Global epidemiology of HIV among female sex workers: influence of structural determinants. Lancet. 2015;385(9962):55-71.

9. Deering KN, Amin A, Shoveller JA, Nesbitt A, Garcia-Moreno C, Duff P, et al. A systematic review of the global magnitude and drivers of violence against sex workers. Am J Public Health. 2014;104(5):e42-54.

10. Operario D, Soma T, Underhill K. Sex work and HIV status among transgender women - systematic review and meta-analysis. J Acquir Immune Defic Syndr. 2008;48(1):97-103.

11. Baral SD, Friedman MR, Geibel S, Rebe K, Bozhinov B, Diouf D, et al. Male sex workers: practices, contexts, and vulnerabilities for HIV acquisition and transmission. Lancet. 2015;385:260-73.

12. Oppal WT. Forsaken: The Report of the Missing Women Commission of Inquiry Executive Summary [Internet]. Vancouver; 2012 [cited 2018 Aug 14]. Available from: http://www.missingwomeninquiry.ca/wp-content/uploads/2010/10/Forsaken-ES-web-RGB.pdf.

13. Strega S, Janzen C, Morgan J, Brown L, Thomas R, Carriére J. Never innocent victims. Violence Against Women. 2014;20(1):6-25. https://doi.org/10.1177/1077801213520576.

14. Global Network of Sex Work Projects. The impact of criminalisation on sex workers' vulnerability to HIV and violence [Internet]. 2017. Available from: http://www.nswp.org/sites/nswp. org/files/impact_of_criminalisation_pb_prf01.pdf.

15. PION. The convention to eliminate all forms of discrimination against women 2017 forms of discrimination against women 2017 - a shadow Report by PION; 2017.

16. Lim S, Peitzmeier S, Cange C, Papworth E, LeBreton M, Tamoufe U, et al. Violence against female sex workers in Cameroon. J Acquir Immune Defic Syndr. 2015;68:S241-7. Available from: http://content.wkhealth.com/linkback/openurl?sid=WKPTLP:landingpage \&an=00126334-201503011-00022.

17. Dewey S, St. Germain T. "It depends on the cop:" street-based sex workers' perspectives on police patrol officers. Sex Res Soc Policy. 2014;11(3):256-70.

18. Ganju D, Saggurti N. Stigma, violence and HIV vulnerability among transgender persons in sex work in Maharashtra, India. Cult Health Sex. 2017;1058(March):1-15. https://doi.org/10. 1080/13691058.2016.1271141.

19. Goldenberg SM, Krüsi A, Zhang E, Chettiar J, Shannon K. Structural determinants of health among im/migrants in the indoor sex industry: experiences of workers and managers/owners in metropolitan Vancouver. PLoS One. 2017;12(1):e0170642. https://doi.org/10.1371/journal. pone. 0170642 .

20. Lam E. Behind the rescue: how anti-trafficking investigations and policies harm migrant sex workers. Toronto: Butterfly Asian and Migrant Sex Workers Support Network; 2018.

21. Mayhew S, Collumbien M, Qureshi A, Platt L, Rafiq N, Faisel A, et al. Protecting the unprotected: mixed-method research on drug use, sex work and rights in Pakistan's fight against HIV/AIDS. Sex Transm Infect. 2009;85(Suppl 2):ii8-16.

22. Decker MR, Wirtz AL, Baral SD, Peryshkina A, Mogilnyi V, Weber RA, et al. Injection drug use, sexual risk, violence and STI/HIV among Moscow female sex workers. Sex Transm Infect. 2012;88(4):278-83. Available from: http://search.ebscohost.com/login.aspx?direct=tru e\&AuthType $=$ cookie,,, shib\&db=rzh\&AN $=104435877 \&$ site $=$ ehost-live .

23. Goldenberg SM, Rangel G, Vera A, Patterson TL, Abramovitz D, Silverman JG, et al. Exploring the impact of underage sex work among female sex workers in two Mexico-US border cities. AIDS Behav. 2012;16(4):969-81.

24. Deering KN, Bhattacharjee P, Mohan HL, Bradley J, Shannon K, Boily M, Ramesh B, et al. Violence and HIV risk among female sex workers in southern India. Sex Transm Dis. 2013;40(2):168-74. 
25. Nemoto T, Boedeker B, Iwamoto M. Social support, exposure to violence and transphobia, and correlates of depression among male-to-female transgender women with a history of sex work. Am J Public Health. 2011;101(10):1980-8.

26. Simić M, Rhodes T. Violence, dignity and HIV vulnerability: street sex work in Serbia. Sociol Health Illn. 2009;31(1):1-16.

27. Surratt HL, Kurtz SP, Chen M, Mooss A. HIV risk among female sex workers in Miami: the impact of violent victimization and untreated mental illness. AIDS Care. 2012;24(5):553-61.

28. Okal J, Chersich MF, Tsui S, Sutherland E, Temmerman M, Luchters S. Sexual and physical violence against female sex workers in Kenya: a qualitative enquiry. AIDS Care. 2011;23:612-8.

29. Decker MR, Crago AL, Chu SKH, Sherman SG, Seshu MS, Buthelezi K, et al. Human rights violations against sex workers: burden and effect on HIV. Lancet. 2015;385(9963):186-99. https://doi.org/10.1016/S0140-6736(14)60800-X.

30. Scorgie F, Vasey K, Harper E, Richter M, Nare P, Maseko S, et al. Human rights abuses and collective resilience among sex workers in four African countries: a qualitative study. Glob Health. 2013;9(1):33.

31. Bourgois P, Prince B, Moss A. The everyday violence of hepatitis $\mathrm{C}$ among young women who inject drugs in San Francisco. Hum Organ. 2004;63(3):253-64.

32. Maher L. Sexed work: gender, race and resistance in a Brooklyn drug market (Clarendon studies in criminology). Oxford: Clarendon Press; 1997. 279 p.

33. Rhodes T, Wagner K, Strathdee S, Shannon K, Davidson P, Bourgois P. Structural violence and structural vulnerability within the risk environment: theoretical and methodological perspectives for a social epidemiology of HIV risk among IDU and SW. In: O'Campo P, Dunn J, editors. Rethinking social epidemiology: towards a science of change. Toronto: University of Toronto Press; 2012.

34. Shannon K, Kerr T, Allinott S, Chettiar J, Shoveller JA, Tyndall MW. Social and structural violence and power relations in mitigating HIV risk of drug-using women in survival sex work. Soc Sci Med. 2008;66:911-21.

35. Syvertsen JL, Bazzi AR. Sex work, heroin injection, and HIV risk in Tijuana: a love story. Anthropol Conscious. 2015;26(2):182-94.

36. Argento E, Reza-Paul S, Lorway R, Jain J, Bhagya M, Fathima M, et al. Confronting structural violence in sex work: lessons from a community-led HIV prevention project in Mysore, India. AIDS Care. 2011;23(1):69-74.

37. Csete J, Cohen J. Health benefits of legal services for criminalized populations: the case of people who use drugs, sex workers and sexual and gender minorities. J Law Med Ethics. 2010;38(4):816-31.

38. Shannon K, Csete J. Violence, condom negotiation, and HIV/STI risk among sex workers. JAMA. 2010;304(5):573. https://doi.org/10.1001/jama.2010.1090.

39. Rhodes T, Simic M, Baros S, Platt L, Zikic B. Police violence and sexual risk among female and transvestite sex workers in Serbia: qualitative study. BMJ. 2008;337(7669):560-3.

40. Krüsi A, Chettiar J, Ridgway A, Abbott J, Strathdee SA, Shannon K. Negotiating safety and sexual risk reduction with clients in unsanctioned safer indoor sex work environments: a qualitative study. Am J Public Health. 2012;102(6):1154-9.

41. World Health Organization. Global and regional estimates of violence against women: prevalence and health effects of intimate partner violence and non-partner sexual violence. Geneva: World Health Organization; 2013.

42. World Health Organization. Preventing suicide: a global imperative. Geneva: World Health Organization; 2014.

43. Zhang L, Li X, Wang B, Shen Z, Zhou Y, Xu J, et al. Violence, stigma and mental health among female sex workers in China: a structural equation modeling. Women Health. 2016;57(6):685-704.

44. Roxburgh A, Degenhardt L, Copeland J. Posttraumatic stress disorder among female streetbased sex workers in the greater Sydney area, Australia. BMC Psychiatry. 2006;6(24):1-12. 
45. Argento E, Duff P, Bingham B, Chapman J, Nguyen P, Strathdee SA, et al. Social cohesion among sex workers and client condom refusal in a Canadian setting: implications for structural and community-led interventions. AIDS Behav. 2016;20(6):1275-83. Available from: http:// www.ncbi.nlm.nih.gov/pubmed/26499335.

46. Blanchard AK, Mohan HL, Shahmanesh M, Prakash R, Isac S, Ramesh BM, et al. Community mobilization, empowerment and HIV prevention among female sex workers in south India. BMC Public Health. 2013;13:234.

47. Kerrigan D, Kennedy CE, Morgan-Thomas R, Reza-Paul S, Mwangi P, Win KT, et al. A community empowerment approach to the HIV response among sex workers: effectiveness, challenges, and considerations for implementation and scale-up. Lancet. 2015;385(9963):172-85.

48. Amnesty International. Sex worker's rights are human rights. London: Amnesty International; 2015.

49. Platt L, Grenfell P, Meiksin R, Elmes J, Sherman SG, Sanders T, et al. Associations between sex work laws and sex workers' health: a systematic review and meta-analysis of quantitative and qualitative studies. PLOS Med. 2018;15(12):e1002680. https://doi.org/10.1371/journal. pmed.1002680.

50. Argento E, Goldenberg SM, Braschel M, Machat S, Strathdee SA, Shannon K. The impact of end-demand legislation on sex workers' access to health and sex worker support services: a community-based prospective cohort study in Canada. PLoS One. 2020;15(4):e225783.

51. Levy J, Jakobsson P. Sweden's abolitionist discourse and law: effects on the dynamics of Swedish sex work and on the lives of Sweden's sex workers. Criminol Crim Justice. 2014;14(5):593-607.

52. Krüsi A, Pacey K, Bird L, Taylor C, Chettiar J, Allan S, et al. Criminalisation of clients: reproducing vulnerabilities for violence and poor health among street-based sex workers in Canada - a qualitative study. BMJ Open. 2014;4:e005191.

53. Le Bail H, Giametta C. What do sex workers think about the French Prostitution Act? A study on the impact of the law from 13 April 2016 against the "prostitution system" in France. Paris; 2018.

54. Jeffrey LA, Sullivan B. Canadian sex work policy for the 21st century: enhancing rights and safety, lessons from Australia. Can Polit Sci Rev. 2009;3(1):57-76.

55. Abel GM, Fitzgerald LJ, Brunton C. The impact of decriminalisation on the number of sex workers in New Zealand. J Soc Policy. 2009;38(03):515-31.

56. Bruckert C, Hannem S. Rethinking the prostitution debates: transcending structural stigma in systemic responses to sex work. Can J Law Soc. 2013;28(01):43-63.

57. Decker MR, Pearson E, Illangasekare SL, Clark E, Sherman SG. Violence against women in sex work and HIV risk implications differ qualitatively by perpetrator. BMC Public Health. 2013;13:876. Available from: http://ovidsp.ovid.com/ovidweb.cgi?T=JS\&PAGE=reference\& $\mathrm{D}=\mathrm{emed} 15 \& \mathrm{NEWS}=\mathrm{N} \& \mathrm{AN}=604576750$.

58. Research for Sex Work. Sex work, HIV/AIDS, public health and human rights [Internet]. Amsterdam; 2003 [cited 2018 Aug 15]. Available from: https://childhub.org/fr/system/tdf/ library/attachments/research_for_sex_work_no_6_.pdf?file=1\&type=node\&id=16708.

59. Ndondo HM, Maseko S, Ndlovu S. Sexual and physical violence against sex workers: a qualitative survey to explore experiences of violence perpetrated by police among sex workers in Victoria Falls, Zimbabwe, 2012. Sex Transm Infect. 2013;89:A312.

60. Popoola BI. Occupational hazards and coping strategies of sex workers in Southwestern Nigeria. Health Care Women Int. 2013;34(2):139-49. https://doi.org/10.1080/07399332.201 1.646366.

61. Strathdee SA, Lozada R, Martinez G, Vera A, Rusch M, Nguyen L, et al. Social and structural factors associated with HIV infection among female sex workers who inject drugs in the Mexico-US border region. PLoS One. 2011;6(4):e19048. Available from: http://www.ncbi. nlm.nih.gov/pubmed/21541349.

62. Baral S, Beyrer C, Muessig K, Poteat T, Wirtz AL, Decker MR, et al. Burden of HIV among female sex workers in low-income and middle-income countries: a systematic review and 
meta-analysis. Lancet Infect Dis. 2012;12(7):538-49. Available from: http://linkinghub.elsevier.com/retrieve/pii/S147330991270066X.

63. Sherman SG, Footer K, Illangasekare S, Clark E, Pearson E, Decker MR. "What makes you think you have special privileges because you are a police officer?" A qualitative exploration of police's role in the risk environment of female sex workers. AIDS Care. 2015;27(4):473-80. https://doi.org/10.1080/09540121.2014.970504.

64. Pando MA, Coloccini RS, Reynaga E, Rodriguez Fermepin M, Gallo Vaulet L, Kochel TJ, et al. Violence as a barrier for HIV prevention among female sex workers in Argentina. PLoS One. 2013;8(1):e54147.

65. Shannon K, Kerr T, Strathdee SA, Shoveller J, Montaner JS, Tyndall MW. Prevalence and structural correlates of gender based violence among a prospective cohort of female sex workers. BMJ. 2009;339:b2939. Available from: http://www.bmj.com.proxy.lib.sfu.ca/content/339/ bmj.b2939.full.

66. Zhang C, Li X, Hong Y, Zhou Y, Liu W, Stanton B. Unprotected sex with their clients among low-paying female sex workers in Southwest China. AIDS Care. 2013;25(4):503-6.

67. Erausquin JT, Reed E, Blankenship KM. Police-related experiences and HIV risk among female sex workers in Andhra Pradesh, India. J Infect Dis. 2011;204(5):S1223-8.

68. Erausquin JT, Reed E, Blankenship KM. Change over time in police interactions and HIV risk behavior among female sex Workers in Andhra Pradesh, India. AIDS Behav. 2015;19(6):1108-15.

69. Platt L, Grenfell P, Bonell C, Creighton S, Wellings K, Parry J, et al. Risk of sexually transmitted infections and violence among indoor-working female sex workers in London: the effect of migration from Eastern Europe. Sex Transm Infect. 2011;87(5):377-84.

70. Prangnell A, Shannon K, Nosova E, DeBeck K, Milloy M-J, Kerr T, et al. Workplace violence among female sex workers who use drugs in Vancouver, Canada: does client-targeted policing increase safety? J Public Health Policy. 2018;39(1):86-99. https://doi.org/10.1057/ s41271-017-0098-4.

71. Lyons CE, Grosso A, Drame FM, Ketende S, Diouf D, Ba I, et al. Physical and sexual violence affecting female sex workers in Abidjan, Côte d'Ivoire. J Acquir Immune Defic Syndr. 2017;75(1):9-17. Available from: http://insights.ovid.com/crossref ?an=00126334-201705010-00002.

72. Lyons T, Krüsi A, Pierre L, Kerr T, Small W, Shannon K. Negotiating violence in the context of transphobia and criminalization: the experiences of trans sex workers in Vancouver, Canada. Qual Health Res. 2015;27:182-90.

73. Poteat T, Wirtz AL, Radix A, Borquez A, Silva-Santisteban A, Deutsch MB, et al. HIV risk and preventive interventions in transgender women sex workers. Lancet. 2015;385(9964):274-86.

74. Landsberg A, Shannon K, Krüsi A, DeBeck K, Milloy MJ, Nosova E, et al. Criminalizing sex work clients and rushed negotiations among sex Workers who use drugs in a Canadian Setting. J Urban Health. 2017;94(4):563-71.

75. Sex Workers' Rights Advocacy Network. Arrest the violence: human rights abuses against sex workers in Central and Eastern Europe and Central Asia. New York: Open Society Foundations; 2009.

76. Open Society Foundations. Criminalizing condoms: how policing practices put sex workers and HIV services at risk in Kenya, Namibia, Russia, South Africa, USA, and Zimbabwe. Sexual Health and Rights Project. New York: Open Society Foundations; 2012.

77. Reza-Paul S, Lorway R, O’Brien N, Lazarus L, Jain J, Bhagya M, et al. Sex worker-led structural interventions in India: a case study on addressing violence in HIV prevention through the Ashodaya Samithi collective in Mysore. Indian J Med Res. 2012;135(1):98-106.

78. Beattie TSH, Bhattacharjee P, Ramesh BM, Gurnani V, Anthony J, Isac S, et al. Violence against female sex workers in Karnataka state, south India: impact on health, and reductions in violence following an intervention program. BMC Public Health. 2010;10:476.

79. Abad N, Baack BN, O’Leary A, Mizuno Y, Herbst JH, Lyles CM. A systematic review of HIV and STI behavior change interventions for female sex workers in the United States. AIDS Behav. 2015;19:1701-19. 
80. Lyons CE, Grosso A, Drame FM, Ketende S, Diouf D, Ba I, et al. Physical and sexual violence affecting female sex workers in Abidjan, Côte d'Ivoire: prevalence, and the relationship with the work environment, HIV, and access to health services. J Acquir Immune Defic Syndr. 2017;75(1):9-17. Available from: http://insights.ovid.com/crossref ?an=00126334-201705010-00002.

81. Lazarus L, Chettiar J, Deering K, Nabess R, Shannon K. Risky health environments: women sex workers' struggles to find safe, secure and non-exploitative housing in Canada's poorest postal code. Soc Sci Med. 2011;73(11):1600-7.

82. Platt L, Grenfell P, Fletcher A, Sorhaindo A, Jolley E, Rhodes T, et al. Systematic review examining differences in HIV, sexually transmitted infections and health-related harms between migrant and non-migrant female sex workers. Sex Transm Infect. 2012;(3):1-10.

83. Shannon K, Strathdee SA, Shoveller J, Rusch M, Kerr T, Tyndall MW. Structural and environmental barriers to condom use negotiation with clients among female sex workers: implications for HIV-prevention strategies and policy. Am J Public Health. 2009;99(4):659-65.

84. Beyrer C, Crago AL, Bekker LG, Butler J, Shannon K, Kerrigan D, et al. An action agenda for HIV and sex workers. Lancet. 2015;385(9964):287-301.

85. Argento E, Goldenberg S, Shannon K. Preventing sexually transmitted and blood borne infections (STBBIs) among sex workers: a critical review of the evidence on determinants and interventions in high-income countries. BMC Infect Dis. 2019;19:212.

86. Beattie TS, Bhattacharjee P, Isac S, Mohan HL, Simic-Lawson M, Ramesh BM, et al. Declines in violence and police arrest among female sex workers in Karnataka state, South India, following a comprehensive HIV prevention programme. J Int AIDS Soc. 2015;18(1):1-16.

87. Lazarus L, Deering KN, Nabess R, Gibson K, Tyndall MW, Shannon K. Occupational stigma as a primary barrier to health care for street-based sex workers in Canada. Cult Health Sex. 2012;14(2):139-50.

88. Beattie TSH, Bhattacharjee P, Suresh M, Isac S, Ramesh BM, Moses S. Personal, interpersonal and structural challenges to accessing HIV testing, treatment and care services among female sex workers, men who have sex with men and transgenders in Karnataka state, South India. J Epidemiol Community Health. 2012;66(2):II42-8.

89. Goldenberg SM, Duff P, Krusi A. Work environments and HIV prevention: a qualitative review and meta-synthesis of sex worker narratives. BMC Public Health. 2015;15(1):1241. Available from: http://www.biomedcentral.com/1471-2458/15/1241.

90. Anderson S, Shannon K, Li J, Lee Y, Chettiar J, Goldenberg S, et al. Condoms and sexual health education as evidence: impact of criminalization of in-call venues and managers on migrant sex workers access to HIV/STI prevention in a Canadian setting. BMC Int Health Hum Rights. 2016;16(1):1-10.

91. Human Rights Watch. Off the streets: arbitrary detention and other abuses against sex workers in Cambodia; 2010.

92. Dimitrov S. In focus Macedonia alert: police raids, detentions, involuntary STI tests; 2008.

93. Asia Catalyst. "Custody and education": arbitrary detention for female sex workers in China; 2013.

94. Magar V. Rescue and rehabilitation: a critical analysis of sex workers' antitrafficking response in India. Signs (Chic). 2012;37(3):619-44.

95. Brents BG, Hausbeck K. Violence and legalized brothel prostitution in Nevada: examining safety, risk, and prostitution policy. J Interpers Violence. 2005;20(3):270-95.

96. Socías ME, Deering K, Horton M, Nguyen P, Montaner JS, Shannon K. Social and structural factors shaping high rates of incarceration among sex workers in a Canadian setting. J Urban Health. 2015;92(5):966-79.

97. Jana S, Basu I, Rotheram-Borus MJ, Newman PA. The Sonagachi Project: a sustainable community intervention program. AIDS Educ Prev. 2004;16(5):405-14.

98. Bhattacharjya M, Fulu E, Murthy L, Seshu M, Cabassi J, VallejoMestres M. The right(s) evidence: sex work, violence and HIV in Asia: a multi-country qualitative study. Bangkok; 2015. 
Open Access This chapter is licensed under the terms of the Creative Commons Attribution 4.0 International License (http://creativecommons.org/licenses/by/4.0/), which permits use, sharing, adaptation, distribution and reproduction in any medium or format, as long as you give appropriate credit to the original author(s) and the source, provide a link to the Creative Commons license and indicate if changes were made.

The images or other third party material in this chapter are included in the chapter's Creative Commons license, unless indicated otherwise in a credit line to the material. If material is not included in the chapter's Creative Commons license and your intended use is not permitted by statutory regulation or exceeds the permitted use, you will need to obtain permission directly from the copyright holder. 